\title{
The Ground Floor of Judaism: Scepticism and Certainty in Moses Mendelssohn's Jerusalem
}

\section{Introduction}

One of the central themes that Moses Mendelssohn's Jerusalem oder über religiöse Macht und Judentum (Jerusalem or on Religious Power and Judaism) is predicated upon is the notion of doubt. Yet in Jerusalem, Mendelssohn seems to employ not just one type, but rather a wide array of varying modes of doubt. The following paper will set out to explore Mendelssohn's equivocal application of doubt in Jerusalem, and in so doing endeavour to demonstrate that he, despite his rather unfavourable view of scepticism as a 'disease of the soul' ('Krankheit der Seele'), ${ }^{1}$ nonetheless draws heavily on it. Indeed, this is by no means a foreign topic to Jewish thought: Already in the first century CE, the Jewish Platonist Philo of Alexandria resorted to Neo-Pyrrhonian and New Academic scepticism to substantiate the ultimate metaphysical truth of Jewish Scripture. ${ }^{2}$ Similarly, we also find references to philosophical scepticism in the work of the medieval Jewish thinker Judah Halevi (1075-1141) and the Venetian Rabbi Simone Luzzatto (?1582-1663). ${ }^{3}$ Furthermore, the Jewish intellectual tradition can be understood as a constant interplay between scepticism and dog-

1 Moses Mendelssohn, Jerusalem or on Religious Power and Judaism, trans. Allan Arkus, Introduction and Commentary by Alexander Altmann (New England: University Press of New England, 1983): 66-67; idem, Jerusalem oder über religiöse Macht und Judentum, in, idem, Gesammelte Schriften. Jubiläumsausgabe (JubA), vol. 8, eds. Ismar Elbogen, Julius Guttmann, Eugen Mittwoch, Alexander Altmann, Eva J. Engel and Daniel Krochmalnik (Bad Cannstatt: Frommann-Holzboog, 1983): 134. Gideon Freudenthal has already pointed this out in his No Religion without Idolatry (Indiana: University of Notre Dame Press, 2012): 22, 41-42. Cf. also Jeremy Fogel, "Scepticism of Scepticism: On Mendelssohn's Philosophy of Common Sense," Melilah 12 (2015): 61. Mendelssohn doesn't refer to scepticism as 'Seelenkrankheit' only in his Jerusalem, but also in his Morgenstunden oder Vorlesungen über das Daseyn Gottes (Berlin: Christian Friedrich Voß, 1785): 144 (JubA 3.2, 72): 'Atheismus und Aberglaube, Zweifelsucht und Schwärmerey, sind beides Krankheiten der Seele, die ihr den sittlichen Tod androhen.'

2 For a detailed analysis of Philo's scepticism, see Carlos Lévy, "La conversion du scepticisme chez Philon d'Alexandrie," in Philo of Alexandria and Post-Aristotelian Philosophy, ed. Francesca Alesse (Leiden and Boston: Brill, 2008): 103-120.

3 For Luzzatto's use of sceptical strategies, see Bill Rebiger, "Sceptical Strategies in Simone Luzzatto's Presentation of the Kabbalists in his Discorso," in Yearbook of the Maimonides Centre for Advanced Studies 2017, ed. Bill Rebiger (Berlin and Boston: De Gruyter, 2017): 51-69; Giuseppe Veltri, Renaissance Philosophy in Jewish Garb: Foundations and Challenges in Judaism on the Eve of Modernity (Leiden and Boston: Brill, 2009): 33-36, 107-108; David B. Ruderman, "Science and Skepticism. Simone Luzzatto on Perceiving the Natural World," in idem, Jewish Thought and Scientific Discovery in Early Modern Europe (Detroit: Wayne State University Press, 1995): 153-184 (5 ${ }^{\text {th }}$ Chapter).

Ә OpenAccess. (c) 2018 Ze'ev Strauss, published by De Gruyter. (cc) BY-NC-ND This work is licensed under the Creative Commons Attribution-NonCommercial-NoDerivatives 4.0 License. 
matism. However, the idea of philosophical doubt has led Mendelssohn-in contrast to the aforementioned Jewish thinkers-in a completely different direction: to an outright repudiation of the pivotal premise of Jewish philosophy, which claims that the Holy Scriptures of Judaism entail eternal philosophical truths ('ewige Vernunftwahrheiten'):

Judaism boasts of no exclusive revelation of eternal truths that are indispensable to salvation, of no revealed religion in the sense in which that term is usually understood. Revealed religion ['geoffenbarte Religion'] is one thing, revealed legislation ['geoffenbarte Gesetzgebung'], another. The voice which let itself be heard on Sinai on that great day did not proclaim, 'I am the Eternal, your God, the necessary, independent being, omnipotent and omniscient, that recompenses men in a future life according to their deeds.' This is the universal religion of mankind, not Judaism; [...]. ${ }^{4}$

In the following article, I wish to argue, both systematically und historically-philologically, that Mendelssohn's basic motivation for resorting to sceptical stances is essentially twofold: He attempts to isolate the core of Jewish belief from philosophical doubt and at the same time expose the conceptual vulnerability of the dogmas of Christianity. The main assertion I will thus develop is that Mendelssohn's exploitation of sceptical concepts comes from the general apologetic impulse for writing Jerusalem. As is known, Mendelssohn formulated this treatise as a reaction against the polemical ultimatum posed anonymously by August F. Cranz (1737-1801) in Das Forschen nach Licht und Recht ${ }^{5}$ to either convert to Christianity or to account for his staying loyal to his Jewish faith while taking his 'enlightened' viewpoint of natural religion into account. ${ }^{6}$ In light of this apologetic and interreligious discourse within which Jerusalem is situated, I will maintain that Mendelssohn endeavours to delineate the crucial differences between Judaism and Christianity through the idea of scepticism. In the process, I will set out to answer two questions: (1) To what aim does Mendelssohn utilise sceptical strategies in Jerusalem for his fundamental understanding of religion and philosophy, revelation and reason? (2) What kind of dif-

4 Mendelssohn, Jerusalem, 97 (JubA 8, 165).

5 August F. Cranz, Das Forschen nach Licht und Recht in einem Schreiben an Herrn Moses Mendelssohn auf Veranlassung seiner merkwürdigen Vorrede zu Manasseh Ben Israel (Berlin, 1782): 9-11. 6 Ibidem, 41: 'So lange Sie diesen Schritt nicht thun, nachdem Sie iezt den ersten gethan haben, steht das Publikum in der allergerechtesten Erwartung, entweder eine Rechtfertigung von Ihnen zu lesen, wie Sie eine so wichtige Abweichung mit der Religion Ihrer Väter vereinbaren wollen, oder-Gründe, die Sie einem öffentlichen Uebergang zu dem Glauben der Christen und dem eigentlichen Christentum selbst entgegen zu setzen haben.' Cf. ibidem, 9. Mendelssohn himself addresses this point explicitly; see his Jerusalem, 86-87 (JubA 8, 152-153). For a more detailed discussion, see Micha Gottlieb, Faith and Freedom: Moses Mendelssohn's Theological-Political Thought (Oxford and New York: Oxford University Pres, 2011): 34 and 51; Shmuel Feiner, Moses Mendelssohn: Sage of Modernity (New Haven and London: Yale University Press, 2010): 150 and 159-176; Elias Sacks, Moses Mendelssohn's Living Script: Philosophy, Practice, History, Judaism (Bloomington and Indianapolis: Indiana University Press, 2017): 25-28, 98 and 176-178. 
ferent sceptical stances does Mendelssohn make use of in Jerusalem? The answer to these questions will unfold in three essential stages. In the first part, I will elaborate on Mendelssohn's understanding of what 'the spirit of true Judaism"7 is as it pertains to his harsh critique (if not sceptical undermining) of Maimonides' dogmatic and philosophical distortion of its 'ancient, original' meaning. ${ }^{8}$ In the second part-drawing on the perceptive and innovative research conducted by Gideon Freudenthal in his No Religion without Idolatry (2012)-I will suggest that Mendelssohn entertains sceptical doubt concerning the nature of language as an effective epistemic vehicle to emphasise the merits of 'the old Judaism' ('das alte Judentum'), which is primarily construed as a system of ceremonial laws ('Zeremonialgesetze'). In this part, light will be shed on a number of theological and philosophical sources that constitute points of departure for Mendelssohn's own stances and discussions. Several of these sources are by no means sceptical in nature, but they still share one unifying feature: They all entail critical inclinations in one way or another towards language and signs. Exactly this common thread seemed to have been cleverly exploited by Mendelssohn and incorporated into his systematic sceptical stance towards language in Jerusalem. In the concluding part, I turn to his employment of a sceptical viewpoint in the framework of his critical analysis of ecclesiastical law ('Kirchenrecht') in the Kingdom of Prussia and the intolerance of the law towards the Jewish population. I will show that Mendelssohn's description relies, in this instance, not so much on ancient scepticism, nor on the Jewish philosophical account of ancient scepticism, but rather specifically on Johann M. Schröckh's fourth volume of his Christliche Kirchengeschichte (1777). ${ }^{9}$

\section{The Non-Speculative Nature of Ancient Judaism}

In one of the central sections of the second part of Jerusalem, Mendelssohn seems to grapple with Cranz's supposition that Judaism has determined articles of faith ('Glaubensartikel der jüdischen Religion'). ${ }^{10}$ The way he proceeds is not by straightforwardly criticizing Cranz, but rather by disputing Maimonides’ dogmatic understanding of Judaism. The specific notion he casts doubt on is Maimonides' contention

7 Mendelssohn, Jerusalem, 100 (JubA 8, 167): 'Geist [...] des ächten Judentums.'

8 JubA 8, 168: 'd[as] alte, ursprüngliche [...] Judentum [...].'

9 Johann M. Schröckh, Christliche Kirchengeschichte, vol. 4 (Leipzig: Engelhart Benjamin Schwickert, 1777).

10 In this context, Cranz refers to the negative article of belief that keeps God's chosen people away from gentiles so their holiness would not be desecrated: 'ist ein Glaubensartikel der jüdischen Religion, nach welchem alle andere Völker, wie eine Art unreiner Geschöpfe angesehen werden, durch deren nähern Umgang das Volk Gottes entheiliget würde;' see idem, Das Forschen nach Licht und Recht, 36. Cranz also alludes to the principles of the Jewish 'church': 'Grundsätze [...] der Kirche;' see ibidem, 13. 
that Jewish faith can at bottom be summed up in thirteen simple principles (עלוש): עשרה עקרים):

\begin{abstract}
Maimonides was the first to conceive of the idea of reducing the religion of his fathers to a certain number of principles, in order that, as he explains, religion, like all other sciences, would have its fundamental conceptions, from which all the others are deduced. This merely accidental idea gave rise to the thirteen articles of the Jewish catechism, to which we owe the morning hymn Yigdal, as well as some good writings by Chasdai, Albo, and Abrabanel. These are all the results they have had up to now. Thank God, they have not yet been forged into shackles of faith. Chasdai disputes them and proposes changes; Albo limits their number and wants to recognize only three basic principles which correspond rather closely to those which Herbert of Cherbury, at a later date, proposed for the catechism; [...]. ${ }^{11}$
\end{abstract}

The tone of Mendelssohn in the quoted passage towards the most celebrated rabbinic authority and Jewish philosopher of the Middle Ages is remarkably critical: He accuses him of advocating nothing short of a reductionist and completely falsified account of Judaism as a set of theoretical beliefs. ${ }^{12}$ Mendelssohn suggests that the historical repudiation of the Maimonidean precepts of faith by major medieval Jewish thinkers, such as Hasdai Crescas (c. 1340 -1410), Joseph Albo (1380-1440) and Isaac Abrabanel (1437-1508), strongly attest to their inauthentic core. With reference to this very passage, Warren Zev Harvey has insightfully pointed out the similarity between Mendelssohn and these medieval anti-Maimonidean thinkers, first and foremost Hasdai Crescas, with respect to their undogmatic conception of Judaism. ${ }^{13}$ A speculative mindset that poses an even greater threat to authentic Judaism is the kabbalistic one, which, according to Mendelssohn, reduces the entire Scripture to 'fundamental doctrines' ('Fundamentallehren') of an utterly speculative nature. ${ }^{14}$

However, my reading of this central passage emphasises another aspect: These important thinkers demonstrated to Mendelssohn exactly how a metaphysical understanding of Holy Scripture not only fails to underpin the absolute truth of Jewish belief, but has the quite counterproductive effect of making Judaism susceptible to philosophical doubt and thus jeopardizing the whole conceptual construct of its

11 Mendelssohn, Jerusalem, 101 (JubA 8, 167). For a more detailed analysis, see Gottlieb, Faith and Freedom, 34-56.

12 Freudenthal, No Religion without Idolatry, 153-154.

13 Warren Zev Harvey, "Hasdai Crescas and Moses Mendelssohn on Beliefs and Commandments," in Moses Mendelssohn: Enlightenment, Religion, Politics, Nationalism, ed. Micha Gottlieb and Charles H. Manekin (Bethesda: University of Maryland Press, 2015): 79-89.

14 Mendelssohn, Jerusalem, 101 (JubA 8, 167). See Harvey, "Hasdai Crescas and Moses Mendelssohn on Beliefs and Commandments," 85. On anti-Kabbalistic tendencies in the Haskalah and preceding, see Bill Rebiger, "The Early Opponents of the Kabbalah and the Role of Sceptical Argumentations: An Outline," in Yearbook of the Maimonides Centre for Advanced Studies 2016, eds. Giuseppe Veltri and Bill Rebiger (Berlin: De Gruyter, 2016): 39-57; Christoph Schulte, "Kabbala in Salomon Maimons Lebensgeschichte", in Kabbala und die Literatur der Romantik: Zwischen Magie und Trope, eds. Eveline Goodman-Thau, Gert Mattenklott and Christoph Schulte (Tübingen: Max Niemeyer Verlag, 1999): $33-66$. 
tradition. This reading is strongly reinforced when we take, for example, Mendelssohn's own reiteration of the main thesis of Jerusalem into consideration-Judaism is not a revealed religion ('geoffenbarte Religion'), but rather revealed legislation ('geoffenbarte Gesetzgebung') - ${ }^{15}$ in An die Freunde Lessings (1786), which he emphasises in conjunction with scepticism and common sense:

When I talk of rational conviction, however, and I want to presuppose this as undoubted in Judaism, the talk is not about metaphysical argumentation as we are used to carrying it on in books, not about pedantic demonstrations that all meet the test of the subtlest skepticism, but about the claims and judgments of a simple, sound commonsense, which looks things right in the eye and reflects calmly. ${ }^{16}$

Mendelssohn makes it abundantly clear that he wishes to establish the Jewish religion as a position that is beyond doubt ('unbezweifelt'); i.e. a stance that, in contrast to metaphysical reasoning ('metaphysische Argumentation'), does not have to withstand the penetrating attacks of philosophical scepticism. ${ }^{17}$

Spinoza's unrelentingly harsh critique in his Tractatus Theologico-Politicus (TTP) of Maimonides' unscientific exegetical method might also have had an effect on this view held by Mendelssohn. ${ }^{18}$ Moreover, the scientific approach applied to biblical exegesis advocated by Spinoza in the TTP-to attempt, through newly developed phi-

15 Mendelssohn, Jerusalem, 97 (JubA 8, 157).

16 I used the English translation found here: Leo Strauss on Moses Mendelssohn, trans. and ed. Martin D. Yaffe (Chicago and London: University of Chicago Press, 2012): 117. Moses Mendelssohn an die Freunde Lessings (Berlin, 1786): 30 (JubA 3.2, 197): 'Wenn ich aber von vernunftmäßiger Ueberzeugung rede, und solche im Judenthum als unbezweifelt voraus setzen will; so ist die Rede nicht von metaphysischer Argumentation, wie wir sie in Büchern zu führen gewohnt sind; nicht von schulgerechten Demonstrationen, die alle Proben des subtilsten Zweifelmuths bestanden sind; sondern von den Aussprüchen und Urtheilen eines schlichten gesunden Menschenverstandes, der die Dinge gerade ins Auge faßt und ruhig überlegt.' To the best of my knowledge, Leo Strauss, in his Einleitung zu 'Morgenstunden' und 'An die Freunde Lessings', is the first to point this out with reference to this specific passage (JubA 3.2, LXVII): 'The connection between his increased inclination toward the philosophy of sound commonsense and his defense of Judaism becomes fully distinct in the following statement in To the Friends of Lessing: [...]. [Der Zusammenhang zwischen seiner verstärkten Neigung zur Philosophie des gesunden Menschenverstandes und seiner Verteidigung des Judentums wird vollends deutlich in folgender Äußerung in dem Schreiben “An die Freunde Lessings"];' see Leo Strauss on Moses Mendelssohn, 117; the original German, see Leo Strauss, Gesammelte Schriften, vol. 2: Philosophie und Gesetz - Frühe Schriften, ed. Heinrich Meier (Stuttgart and Weimar: J. B. Metzler, $\left.{ }^{2} 2013\right): 579$. Cf. Freudenthal, who develops this point much further and was the first to link it to Mendelssohn's scepticism regarding language; see idem, No Religion without Idolatry, 28-29.

17 Freudenthal elucidates this important aspect of Mendelssohn's thought in a very systematic manner: No Religion without Idolatry, 21-64 (Ch. 1. Mendelssohn: Common Sense, Rational Metaphysics, and Skepticism).

18 For a more detailed analysis, see Julius Guttmann, "Mendelssohns Jerusalem and Spinozas Theologisch-Politischer Traktat," in Achtundvierzigster Bericht der Hochschule für die Wissenschaft des Judentums in Berlin N. 24, Artilleriestraße 14 (Berlin: 1931): 31-67; Micha Gottlieb, Faith and Freedom, 9-12 and $24-54$. 
lological tools, to unearth the original meaning of Scripture, unfiltered by theological premises-gained a strong foothold in the intellectual Protestant circles in the German-speaking world of the eighteenth century and was further cultivated. Protestant philologists of Biblical Hebrew, such as Johann W. Meiner (1723-1789), Robert Lowth (1710 - 1787), Johann D. Michalis (1717-1791), Johann G. Herder (1744-1803) and Johann G. Eichhorn (1752-1827), seem to have had a great impact on Mendelssohn's perception of the Hebrew Bible as an aesthetic piece of writing. ${ }^{19}$ The progress in the field of Biblical Hebrew could have facilitated Mendelssohn's uncovering of the philological shortcomings of the presuppositions upon which much of Jewish philosophy is grounded. Mendelssohn was not only familiar with Spinoza's critique of Maimonides, but also with that of Protestant authors. If we take, for example, the first volume of Heinrich Corrodi's Kritische Geschichte des Chiliasmus (1781), a book Mendelssohn was familiar with, ${ }^{20}$ we find a fierce critique of Maimonides' as nothing less than a 'fraudulent' Aristotelian exegesis of Jewish Scripture:

Maimonides deceives himself, insofar as he does not derive his philosophy from Jewish Scriptures, but from Aristotle; this was also done by those, who solely recognised a reasonable system of philosophy and not that of the sinister kabbalistic web of dreams. For they didn't find what they were looking for in the philosophy of their nation. ${ }^{21}$

The attitude of these theologians of the German-speaking world towards the exegetical rabbinic tradition as a whole was very deprecatory, since it made speculative assumptions superimposed on Jewish Scripture. In the section "Talmud und Rabbinen" (III. § 341: “Schriften der Rabbinen”) of Eichhorn's pioneering three-volume Einleitung ins Alte Testament (1780-1783), which Mendelssohn possessed in its entirety in his library, ${ }^{22}$ he assesses their Scriptural interpretation as unscientific. For this reason, he emphasises that his analysis of the Biblical corpus will not depend on their uncritical judgments. ${ }^{23}$ It is, of course, plausible that the 'nervensaftverzehrende' Kri-

19 See Verzeichniß der auserlesenen Büchersammlung des seeligen Herrn Moses Mendelssohn (Berlin: 1786): 13 (№ 198), 14 (nํs 215-216, $219-231), 25$ (№ 81), 27 (nos 166-168), 30 (№ 227), 33 (№ 272 ), 36 (№ 321), 33 (№ 272), 44- 45 (n-o 501-511, 530).

20 See Verzeichniß, 23 (n-s 97-99).

21 Heinrich Corrodi, Kritische Geschichte des Chiliasmus, vol. 1 (Frankfurt and Leipzig, 1781): 26-27 (fn. *; my translation): 'Maimonides straft sich auch dadurch selbst Lügen, daß er seine Philosophie nicht aus den jüdischen Schriften, sondern aus Aristoteles schöpft, auch haben das alle gethan, die ein erträgliches System der Philosophie und nicht das finstere kabbalistische Geweb von Träumereyen allein kannten. Denn sie fanden in der Philosophie ihrer Nation nicht was sie suchten.' Corrodi characterises the exegetical method of Philo of Alexandria, 'der platonisierende Jude,' in analogous terms; see ibidem, 42: 'Philo [...] hat ein System, das offenbar aus dem Platonischen entstanden ist.' 22 Verzeichniß, 27 (n-0s 166-168).

23 Johann G. Eichhorn, Einleitung ins Alte Testament, vol. 2 (Leipzig: Weidmanns Erben und Reich, 1781): 8: 'Nicht auf ihre Urtheile bauen wir unsre Vorstellungen von der jetzigen Beschaffenheit des Hebräischen Textes, sondern auf das, was Erfahrung und kritische Untersuchung desselben uns gelehrt hat.' 
tik der reinen Vernunft $(\mathrm{KrV})^{24}$ 'des alles zermalmenden Kants, ${ }^{25}$ published only two years prior to Jerusalem in 1781, illustrated to Mendelssohn the striking epistemological limitations of speculative metaphysics and the implications this insight might have on $a$ Judaism that is strongly premised on theoretical notions. ${ }^{26}$

\section{Scepticism and the Non-Verbality of Mosaic Law}

Subsequently, Mendelssohn considerably widens the scope of the problem concerning theological dogmatism within the framework of Judaism: He proceeds to doubt entirely the capacity of the fixed written and spoken word as a symbol for mediating the true lively essence of Judaism and metaphysical truth. The immediate reason for his addressing this issue seems to be rooted in the following statement Cranz made in the opening of Das Forschen nach Licht und Recht:

This figurative expression [i.e. of Moses covering his radiant face] probably signifies nothing more than that there was a time when the eyes of as-yet-unenlightened nations were still unable to bear the truth pure and whole, and that there came another time when people dared to take a longer glimpse at the bright sun and considered themselves strong enough to throw away the veil, and, speaking frankly, to teach in an unconcealed manner what had otherwise only been cloaked in hieroglyphics and more than halfway veiled in figurative expressions. ${ }^{27}$

In this quotation, Cranz attempts to describe the conceptual progression Christianity has made with respect to Judaism, the belief system it evolved from: 'In the period of the so-called New Testament, the Christians boasted of seeing Moses with his face uncovered.'28 This passage revolves around the New Testament metaphoric ('bildli-

24 JubA 13, 100.

25 Mendelssohn, Morgenstunden, IV. Fogel also alludes to this specific characterisation of Kant by Mendelssohn: "Scepticism of Scepticism: On Mendelssohn's Philosophy of Common Sense," 62. It should be noted that Mendelssohn did not possess the KrV in his library, but the Prolegomena zu einer jeden künftigen Metaphysik, die als Wissenschaft wird auftreten können, which was published like Jerusalem in 1783. See Verzeichniß: 29, № 205; see also ibidem, nos 38-41, n-o $353-355$ ).

26 Freudenthal, No Religion without Idolatry, 32 and 38-40.

27 August F. Cranz, "The Search for Light and Right in a Letter to Mr. Moses Mendelssohn, on the Occasion of his Remarkable Preface to Menasseh ben Israel," in Moses Mendelssohn: Writings on Judaism, Christianity \& the Bible, ed. Micha Gottlieb (Waltham: Brandeis University Press 2011): 55-56; Cranz, Das Forschen nach Licht und Recht, 5-6. Attention has already been drawn to this important link by several researchers, cf. Jeffrey S. Librett, The Rhetoric of Cultural Dialoge: Jews and Germans from Moses Mendelssohn to Richard Wagner and Beyond (Stanford: Stanford University Press, 2000): 48-50; Christiane Frey, "Gramma Hieroglyphe und jüdisch-hebräische Kultur (Herder, Dohm, Mendelssohn)," in Die Ordnung der Kulturen: zur Konstruktion ethnischer, nationaler und zivilisatorischer Differenzen 1750-1850, eds. Hansjörg Bay and Kai Merten (Würzburg: Königshausen \& Neumann, 2006): $149-151$.

28 Cranz, "The Search for Light and Right in a Letter to Mr. Moses Mendelssohn," 55; idem, Das Forschen nach Licht und Recht, 5. 
che Vorstellungsart') in 2 Corinthians 3:13-18, which is in turn an allusion to the radiant face of the Jewish lawgiver depicted in Exodus 34:29-35 - the point being that Jewish belief has only an oblique access to the Godly mysteries, in contrast to the Christian faith, which gains unmediated insight into these revealed truths. ${ }^{29}$ Cranz seems to explicate this metaphor, which he regards as an insinuation of the spiritual backwardness of Judaism, which can grasp God only in his concealment (Deus absconditus), in terms of the semiotic notion conveyed in 2 Corinthians 3:6: For the letter

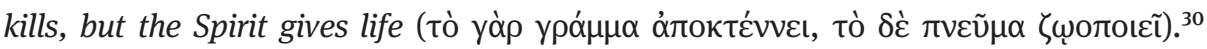
Cranz implies that Jewish faith is by definition reliant upon the intermediation of signs in the form of the figurative Biblical Hebrew language ('in Hieroglyphen kleidete, und in figürlichen Vorstellungsarten'). It is quite apparent that Mendelssohn's Jerusalem directly quarrels with Cranz's Christocentric apprehension of Judaism as conveyed in the above-mentioned passage on the veiled face of the Jewish lawgiver. Two reasons present themselves for this claim: (1) Mendelssohn also alludes to hieroglyphs in juxtaposition with Biblical Hebrew as an epistemological obstacle to the original unmediated truths of the Sinaitic revelation. ${ }^{31}$ (2) He employs the Pauline symbols of dead letter ('toter Buchstabe') and lively spirit ('lebendiger Geist') in 2 Corinthians 3:6 at the centre of his depiction of the true nonverbal, spiritual nature of Judaism as ceremonial law ('Zeremonialgesetz'). ${ }^{32}$

It seems, however, to be a bit perplexing that Cranz juxtaposes the Biblical Hebrew, spoken by the veiled Moses to the Israelites, with hieroglyphs. A possible explanation can be traced back to De vita Moysis I 23 of Philo of Alexandria, which describes how Moses in his adolescence was instructed by knowledgeable Egyptians in

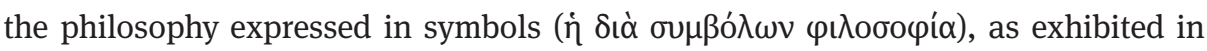

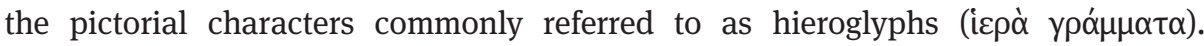
Cranz, a trained theologian from the University of Halle, ${ }^{33}$ was surely acquainted to some extent with the body of thought of the Jewish Alexandrian. Moreover, in 1778, just four years prior to Cranz's response to Mendelssohn's Preface to Menasseh

29 Cf. Librett, The Rhetoric of Cultural Dialoge, 48-50; Frey, "Gramma Hieroglyphe und jüdisch-hebräische Kultur (Herder, Dohm, Mendelssohn)," 149-151.

30 See Daniel Krochmalnik, "Das Zeremoniell als Zeichensprache: Moses Mendelssohns Apologie des Judentums im Rahmen der aufklärerischen Semiotik," in Fremde Vernunft. Zeichen und Interpretationen, vol. 4, eds. Josef Simon and Werner Stegmaier (Frankfurt am Main: Suhrkamp, 1998): 274275 and 278; Librett, The Rhetoric of Cultural Dialoge, 49; Frey, "Gramma Hieroglyphe und jüdisch-hebräische Kultur (Herder, Dohm, Mendelssohn)," 150.

31 Mendelssohn, Jerusalem, 108-111 (JubA 8, 184-185). See Freudenthal, No Religion without Idolatry, 105-134 (Ch. 5: Idolatry: Egyptian and Jewish); Veltri, Renaissance Philosophy in Jewish Garb, 169194 (Ch. 8 Ceremonial Law: History of a Philosophical-Political Concept); Sacks, Living Script, 11-12 and 22-60.

32 Mendelssohn, Jerusalem, 108 (JubA 8, 184).

33 See Dieter Reichelt, August Friedrich Cranz: Ein Kgl. Preußischer Kriegsrath als Schriftsteller von Profession. Zeugnisse aus seinem merkwürdigen Leben und Wirken in Berlin (Bargfeld: Luttertaler Händedruck 1996): 60. 
Ben Israel (Vorrede zu Manasse ben Israel: Rettung der Juden), De vita Moysis I-II (Mos.) was published anonymously in a German translation under the title Philo vom Leben Moses, ${ }^{34}$ where he could have encountered this passage, which reads as follows:

These [i.e. the learned Egyptians] further instructed him [i.e. Moses] in the philosophy conveyed in symbols, as displayed in the so-called holy inscriptions and in the regard paid to animals, to which they even pay divine honours. ${ }^{35}$

This suggestion doesn't seem farfetched at all if, for example, we take into consideration that this topic, with reference to this very Philonic account of Moses' intellectual formation, was mentioned in Schiller's Die Sendung Moses from 1790. ${ }^{36}$

34 Philo vom Leben Moses, das ist: von der Gottesgelahrheit und dem prophetischen Geiste (Dresden: Waltherische Hofbuchhandlung, 1778).

35 Philo. In Ten Volumes (PLCL), vol. 6, trans. Francis H. Colson (Cambridge, MA: Harvard University Press, $\left.{ }^{5} 1984\right):$ :287-289. For this passage in the German translation used by Mendelssohn, see: 'Es brachten ihm aber die Aegyptischen Gelehrten [...] die symbolische Weltweisheit, welche in den sogenanten heiligen Schriften durch Bilder gewisser vorzüglicher Thiere, welche sie auch göttlich verehren, gelehrt wird.' (Gottesgelahrheit, 12-13)

36 Friedrich von Schiller, Sämmtliche Werke, vol. 7 (Stuttgart and Tübingen: J. G. Cotta‘sche Verlagsbuchhandlung, 1819), 70: 'Der Geschichtschreiber Philo sagt, Moses sei von den ägyptischen Priestern in der Philosophie der Symbolen und Hieroglyphen wie auch in den Geheimnissen der heiligen Tiere eingeweiht worden. Eben dieses Zeugnis bestätigen mehrere, und wenn man erst einen Blick auf das, was man ägyptische Mysterien nannte, geworfen hat, so wird sich zwischen diesen Mysterien und dem, was Moses nachher getan und verordnet hat, eine merkwürdige Aehnlichkeit ergeben.' For an analysis of this motif in Schiller's Die Sendung Moses, see Frey, "Gramma Hieroglyphe und jüdisch-hebräische Kultur (Herder, Dohm, Mendelssohn),” 151 and 157-158. Cf. William Warburton, Die göttliche Sendung Mosis, aus den Grundsätzen der Deisten bewiesen, vol. 3 (Frankfurt and Leipzig: Johann Gottlieb Vierling, 1753): 104 (fn. i): 'Philo führet in seiner Lebensbeschreibung Mosis, die Egyptischen Priester ein, und lasset sie nach Platonischen Grundsätzen von der Seele, welche den Leib Mosis belebt, sich bei sprechen; welches eben so klug geurtheilet heißt, als wenn ein neuer Scribent, welcher das Leben des Ptolomäus, des Sternsehers, schriebe, ihn die Grundsätze des Herrn Isaac Newtons erklären ließe.' Mendelssohn mentions the German translation of The Divine Legation of Moses Demonstrated in his recension of Joseph Warton's An Essay on the Writing and Genius of Pope; see JubA 4, 323. For the significance of Warburton, see Freudenthal, No Religion without Idolatry, 94-95, 106, 116-117, 121-124, 250, 273-275, and 278-279; cf. Krochmalnik, "Das Zeremoniell als Zeichensprache,” 263 and 279-284. Cf. Paul E. Jablonski's Pantheon Aegyptiorum, a work Mendelssohn was well familiar with; see JubA 5.2, 113. Jablonski mentions Philo's understanding of the sin of the golden calf in Mos. 2.161-162 as a regression to Egyptian idolatry; see idem, Pantheon Aegyptiorum, Sive de Diis Eorum Commentarius: Cum Prolegomenis de Religione Et Theologia Aegyptiorum, vol. 1 (Frankfurt an der Oder: 1750), 180: ‘[...] ubi de idolotaria israelitarum, vitulum aureum in deserto




Cf. Mendelssohn's depiction in Jerusalem: 'Schon in den ersten Tagen der so wundervollen Gesetzgebung fiel die Nation in den sündlichen Wahn der Aegyptier zurück, und verlangte ein Thierbild' (emphasis in original). 
With respect to Mendelssohn, we can easily establish his well-founded familiarity with this specific Philonic writing: He not only possessed the German translation in his library ${ }^{37}$ but even alludes, in three significant instances, in his Bi'ur (ספר נתיבות to themes directly stemming from Mos. ${ }^{38}$ In his introduction to the Bi'ur, he twice refers to Philo's depiction of the Greek translation of Hebrew Scripture:

\begin{abstract}
And also Yedidia ha-Alexandroni, who is called Philo, [together with Josephus Flavius] describe this event in accordance with the abovementioned account of Aristeas, with some slight modifications and a more succinct description, in such a manner indicating that what they said was from this Greek book [i.e. Letter of Aristeas] [...]. [...]: it would thus appear that we mustn't deny the testimony of the ancients in regard to this, in particular the testimony of Philo, who was one of the citizens of Alexandria itself, the city in which the elderly completed this translation work three hundred years before him, and the testimony of several Christian scholars that lived at the times of the first Tannaim, for they all agree about the entire story of Aristeas, [...]. ${ }^{39}$
\end{abstract}

In his commentary to Exodus 25:4, he mentions the understanding of the 'wise Philo'


uities [i.e. Antiquitates Judaicae] and the wise Philo in his book The Life of Moses refer to it as purple-red [...]. ${ }^{40}$ Mendelssohn could have also been confronted with the significance of Philo's depiction, in Mos. 1.23, of Moses' Egyptian educational for-

37 Verzeichniß, 34 (№ 275).

38 For a more detailed analysis of the reception of Philo of Alexandria in the Haskalah, see Ze'ev Strauss, Rabbi Jedidjah ha-Alexandri. Die Wiederentdeckung der Religionsphilosophie des Philon von Alexandria in der osteuropäischen Haskala (Berlin and Boston: De Gruyter, forthcoming 2019).



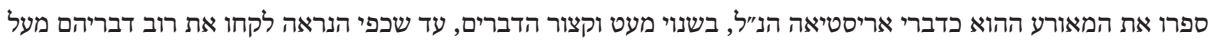

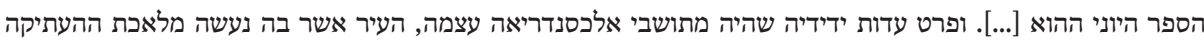

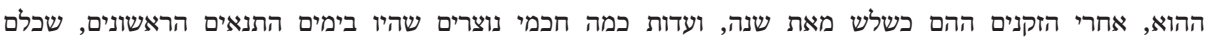
"מסכימים בכללות הספור של אריסטיאה, [...].]

40 JubA 16, 240 (my translation). Mendelssohn's translation reads accordingly as follows: 'Auch himmelblauen, purpurrorthe und hochrothe Wolle, und Leinengarn und Ziegenhaare.' (my emphasis) He

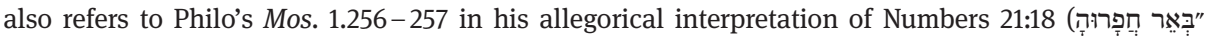
"שָׁרים); (ספר נתיבות שלום והוא חבור כולל חמשה חומשי תורה (במדבר (Prague: verlag des S.

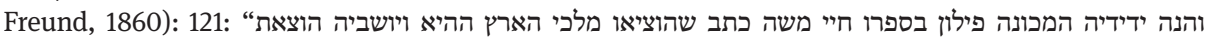



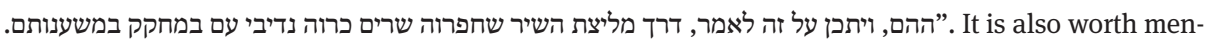
tioning that Johann B. Kölbele, in his polemic letter to Mendelssohn (1770), implicitly endeavours to identify Mendelssohn with Philo: 'Die Gottheit Christi und die damit genau verbundene Lehre von der Heiligen Dreyeinigkeit solten wenigstens einen Platonisierenden, Philonisierenden, und Kabalistischen Juden nicht sehr befremden [...];' see idem, 'Zweites Schreiben an Herrn Moses Mendelssohn insonderheit über den ehemaligen Mendelssohnischen Deismus, über das Mendelssohnische Kennzeichen einer Offenbarung, und kürzlich über die Glaubwürdigkeit der Evangelischen Geschichte,” in Carl Bonnet, Philosophische Untersuchung der Beweise für das Christenthum. Samt desselben Ideen von der künftigen Glückseligkeit des Menschen, Teil 2: Sammlung derer Briefe, welche bey Gelegenheit der Bonnetschen philosophischen Untersuchung der Beweise für das Christenthum, zwischen Hrn. Lavater, Moses Mendelssohn, und Hrn. Dr. Kölbele gewechselt worden (Frankfurt am Main: Johannes Bayrhoffer, 1774): 131. 
mation in John Spencer's De Legibus Hebraeorum Ritualibus et Earum Rationibus Libri Quatuor (1732), a work he possessed in folio format in his library. ${ }^{41}$ Spencer took it upon himself, in the words of Jan Assmann, to prove the 'Egyptian origin of the ritual laws of the Hebrews. ${ }^{, 42}$ Assmann regards this short Philonic passage as decisive for Spencer's Egyptian portrayal of Moses:

Moses certainly knew hieroglyphic writing, which Spencer takes to be a secret code by which the Egyptian priests transmitted their wisdom to the initiated. His sources include Philo of Alexandria, De Vita Mosis, book 1, where we read that Moses learned from his Egyptian masters, among other subjects, ten dia symbolon philosophian. ${ }^{43}$

Our proposed reading is substantiated even further if we account for the fact that Cranz probably reacted not only to Mendelssohn's Vorrede, the German translation of Menasseh Ben Israel's Vindicia Judaeorum (1656), but also to the contents of the translated essay itself. This is due to the fact that Philo occupies a crucial position in Rettung der Juden, written by Spinoza's Amsterdam rabbi, which makes numerous references to the historical descriptions of the Jewish Alexandrian to illustrate the hardships Jews endured under the rule of the Roman Empire. ${ }^{44}$ For precisely this reason, Mendelssohn makes the following observation regarding Ben Israel's drawing on Philo (and Josephus Flavius):

41 Verzeichniß, 4 (№ 58).

42 Jan Assmann, Moses the Egyptian: The Memory of Egypt in Western Monotheism (Cambridge, MA and London: Harvard University Press, 1997): 56.

43 Ibidem, 73. See also ibidem, 56: 'For Spencer's project, this short sentence [i.e. that, according to St. Stephanus, 'Moses was well versed in all the wisdom of the Egyptians'] was absolutely crucial. It was the one foundation on which he could build his entire edifice, and it was the one testimony that could save him from being accused of heresy. Serving as leitmotifs throughout the whole line of the Moses debate, which started with Spencer [...], are this sentence and a short passage from Philo of Alexandria in De Vita Mosis in which he says that Moses was initiated into the "symbolic" philosophy of the ancient Egyptians.' Spencer's reliance upon Philo is very striking; in this work, the Jewish Platonist seems to hold the most important position by far amongst Jewish thinkers. Another book that is worth drawing attention to in this context is Ralph Cudworth, The True Intellectual System of the Universe: Wherein all the Reason and Philosophy of Atheism is Confuted and its Impossibility Demonstrated with a Discourse concerning the True Notion of the Lords Supper (New York: Gould \& Newman, 1837), which Mendelssohn possessed in folio and in Mosheim's Latin translation (Verzeichniß, 4: $\mathrm{n}^{\mathrm{0}} \mathrm{S}$ 67-68); see ibidem, 416: 'For which cause, we can by no means give credit to that of Philo, in the life of Moses, that besides the Egyptian priests, learned men were sent by Pharaoh's daughter out of Greece to instruct Moses.' Cf. Ludwig Holberg, Jüdische Geschichte: von Erschaffung der Welt bis auf gegenwärtige Zeiten, vol. 1 (Altona and Flensburg: Verlag der Gebrüder Korte, 1747): 109: 'Moses wird an dem ägyptischen Hofe erzogen: Nach einigen Jahren lies die Fürstin Mosen zu sich kommen, und nahm denselben nicht aus nur als ihr eignes Kind auf, sondern sie lies ihn auch in allen ägyptischen Künsten und Wissenschaften aufs sorgfältigste unterrichten. Das beste aber, nämlich die Erkenntnis des wahren Gottes hatte er bereits durch den Unterricht seiner Eltern gefaßt.'

44 Mendelssohn, Menasseh Ben Israel. Rettung der Juden: Aus dem Englischen übersetzt nebst einer Vorrede von Moses Mendelssohn (Berlin and Stettin: Friedrich Nicolai 1782): 36-39 and 47. 
If in this passage we should understand by empire of honour a certain empire in the world, then the only possible thing that could be meant is the reign of the Roman Empire, under which the Jews in those days lived and during which this prayer was introduced. How can this, however, be reconciled with the assertion of our Rabbi [i.e. Menasseh Ben Israel], which demonstrates this from passages of Josephus and Philo, namely that the Jews sacrificed and prayed for the wellbeing of the Roman emperor? Indeed, according to the dictum of the rabbis the sin altogether, but not the sinner, should be anathematised ${ }^{45} .46$

Mendelssohn does not merely reaffirm Cranz's theological critique concerning the metaphorical language of ancient Hebrew, but further develops this line of thought into a well-thought-out sceptical stance in regard to the epistemic status of language altogether:

Doctrines and laws, convictions and actions. The two former were not connected to words or written characters which always remain the same, for all men and all times, amid all the revolutions of language, morals, manners, and conditions, words and characters which invariably present the same rigid forms, into which we cannot force our concepts without disfiguring them. [...] The ceremonial law itself is a kind of living script, rousing the mind and heart, full of meaning, never ceasing to inspire contemplation and to provide the occasion and opportunity for oral instruction. [...] We teach and instruct one another only through writings; we learn to know nature and man only from writings. We work and relax, edify and amuse ourselves through overmuch writing. [...] Everything is dead letter ['toter Buchstabe']; the spirit of living conversation has vanished. [...] In a word, we are literati, men of letters ['Buchstabenmenschen']. Our whole being depends on letters; and we can scarcely comprehend how a mortal man can educate and perfect himself without a book. ${ }^{47}$

Gideon Freudenthal has convincingly shown that this sceptical position towards language advocated for by Mendelssohn is not only unique to his Jerusalem but constitutes a systematic philosophical viewpoint of his later years which also correlates with his common-sense tendency:

45 See Babylonian Talmud, Berakhot 10a. Cf. Mendelssohn, Jerusalem, 124-125 (JubA 8, 190): 'And if this is the case, I cannot fear such a condition; nor can I wish for a revelation [assuring me] that I shall never be placed in this condition of magnanimous benevolence which brings felicity to my fellow creatures and myself. What I have to fear is sin itself.'

46 Ibidem, 30 -31 (fn. *; my translation and emphasis). Cf. JubA 8, 48: 'Wenn in dieser Stelle unter Reiche des Stoltzes ein gewisses Reich auf Erden verstanden werden soll; so kann wohl kein anderes, als das Römische gemeinet seyn, unter dessen Drucke die Juden damals lebten, als dieses Gebet eingeführet worden. Wie räumt sich dieses aber mit dem, was unser Rabbi in der Folge behauptet, und durch Stellen aus dem Josephus und Philo beweiset, daß nehmlich die Juden für das Wohl der römischen Kaiser und des Reichs geopfert und Gebete angestellet? Ja, nach dem Ausspruch der Rabinen überhaupt soll der Sünde, aber nicht dem Sünder geflucht werden' (my emphasis).

47 Mendelssohn Jerusalem, 102-104 (original emphasis) (JubA 8, 169-170). Cf. Julius Guttmann, Die Philosophie des Judentums (Wiesbaden: Fourier Verlag, 1985): 314. Krochmalnik, "Das Zeremoniell als Zeichensprache," 270 - 274; Ulrich Ricken, "Mendelssohn und die Sprachtheorien der Aufklärung," in Moses Mendelssohn im Spannungsfeld der Aufklärung, eds. Michael Albrecht and Eva J. Engel (Stuttgart: Frommann-Holzboog, 2000): 228-229. 
And yet readers cannot ignore his repeated advocacy of common sense or sound reason and his reservations concerning metaphysics as such. Scholars wished to attenuate this inconsistency and suggested that at first Mendelssohn was a Wolffian metaphysician but that he grew ever more sceptical regarding metaphysics and more inclined to common sense. ${ }^{48}$

As Freudenthal argues, Mendelssohn is to be regarded as 'a common-sense philosopher and sceptic in metaphysics, ${ }^{, 49}$ who became increasingly doubtful of 'the ability of language to adequately represent and to help generate truth transcending common-sense knowledge of the empirical world. ${ }^{50}$ Mendelssohn's apprehension of Judaism is nothing short of puzzling: Hebrew Scripture, when taken for the absolute truth, leads to idolatry. ${ }^{51}$ I would like to make five observations regarding the quotation at hand:

1) Mendelssohn's sceptical evaluation of language, in all likelihood, draws upon Plato's Schriftkritik in the Phaedrus (274b-278e), where Plato puts the following statement into the mouth of Socrates:

Writing, Phaedrus, has this strange quality, and is very like painting; for the creatures of painting stand like living beings, but if one asks them a question, they preserve a solemn silence. And so it is with written words; you might think they spoke as if they had intelligence, but if you question them, wishing to know about their sayings, they always say only one and the same thing. And every word, when once it is written, is bandied about, alike among those who understand and those who have no interest in it, and it knows not to whom to speak or not to speak; when ill-treated or unjustly reviled it always needs its father to help it; for it has no power to protect or help itself. (Phdr. 275d4-e5) $)^{52}$

48 Freudenthal, No Religion without Idolatry, 13. Fogel also follows this line of interpretation: "Scepticism of Scepticism: On Mendelssohn's Philosophy of Common Sense," 54 and 58-67.

49 Freudenthal, No Religion without Idolatry, 17.

50 Ibidem, 16.

51 In this context, Mendelssohn refers explicitly to Christoph Meiners' Versuch über die Religionsgeschichte der ältesten Völker, besonders der Egyptier (Göttingen: Johann Christian Dietrich, 1775): 'Mr. Meiners's remark would accordingly be a sort of confirmation of my hypothesis that the need for written characters was the first cause of idolatry. In judging the religious ideas of a nation that is otherwise;' see Mendelssohn, Jerusalem, 113 (JubA 8, 179); see Alexander Altmann's commentary, Jerusalem, 27. I believe Mendelssohn is alluding to another passage of Meiners than the one suggested by Alexander Altmann: '[...]: dringt man aber tiefer ein, so findet man den vollständigsten Stammbaum der Abgötterey, eine ununterbrochene Folge, und leicht begreiflich Zeugung aller Arten von Irrthümern, die so wie sie sind, nothwendig auseinander entstehen mußten. Die Grundbegriffe dieser ganzen Irr-Theorie gründeten sich in der Lage und Beschaffenheit des Landes, in der Lebensart der Einwohner. [...]: diese verbunden mit den Hieroglyphen konnten keinen andern, als einen solchen Zustand der Gelehrsamkeit erzeugen;' see Meiners, Versuch über die Religionsgeschichte der ältesten Völker, 62.

52 Plato, Euthyphro, Apology, Crito, Phaedo, Phaedrus, trans. Harold N. Fowler (Cambridge, MA and London: Harvard University Press, 2005): 565-567. Mendelssohn refers to Plato's distinction of earthly and heavenly $\varepsilon \rho \omega \varsigma$ and exploits it for his own differentiation between worldly and otherworldly politics; see Mendelssohn, Jerusalem, 131 (JubA 8, 196). 
The main similarity in this respect between Mendelssohn and Plato is grounded on the almost identical dichotomy between the living word (spoken) and the inanimate one (written), which both equate with an image. In Phdr. 276a, we read: 'You mean

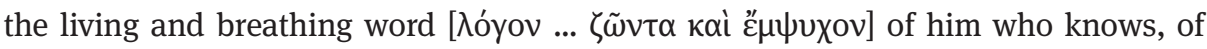

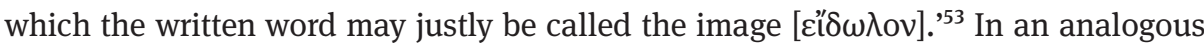
manner, Mendelssohn juxtaposes written language as 'permanent signs' ('fortdauernde Zeichen') with the notion of an image:

We have seen how difficult it is to preserve the abstract ideas of religion among men by means of permanent signs. Images and hieroglyphics ['Bilder und Bilderschrift'] lead to superstition and idolatry, and our alphabetical script makes man too speculative. It displays the symbolic knowledge of things and their relations too openly on the surface; it spares us the effort of penetrating and searching, and creates too wide a division betwe[e]n doctrine and life. ${ }^{54}$

Mendelssohn's explicit and overtly approving references, in this very section, to Meiners' Versuch über die Religionsgeschichte der ältesten Völker, besonders der Egyptier (1775) ${ }^{55}$ solidifies our hypothesis further, since the author makes recourse in this work to Plato's critique of written language. The philosopher and historian Christoph Meiners (1747-1810) partially translates and then comments on Socrates' portrayal of Thamus' condemnation of Theuth's invention of letters (ypá $\mu \mu \alpha \tau \alpha)(P h d r$. $274 \mathrm{c} 5-275 \mathrm{~b} 2) .{ }^{56}$

2) Mendelssohn's innovative solution to this problem, the ceremonial law perceived as 'living script,' could also be linked to the Platonic Schriftkritik in the Phaedrus: If our earlier suspicion is correct as to the impact Philo's De vita Moysis had on Mendelssohn's perception of Judaism, then one should at this juncture bear in mind Philo's Platonic depiction of Mosaic law, which is unequivocally predicated on Plato's

53 Plato, Euthyphro, Apology, Crito, Phaedo, Phaedrus, 567. Cf. Krochmalnik, "Das Zeremoniell als Zeichensprache," 274-275; Grit Schorch, Moses Mendelssohns Sprachpolitik (Berlin and Boston: De Gruyter, 2012): 228, n. 52.

54 Mendelssohn, Jerusalem, 118 (JubA 8, 184).

55 Mendelssohn, Jerusalem, 112-113 and 121 (JubA 8, 177-179 and 186). The influence of this document on Mendelssohn's Jerusalem has been already pointed out by Alexander Altmann in the commentary to the English translation: 223-224. See also the insightful remarks on the subject in Freudenthal, No Religion without Idolatry, 106 and 273.

56 Meiners, Versuch über die Religionsgeschichte der ältesten Völker, 208-209: 'Ich habe von einem


nur die Kunst zu zählen, sondern auch die Kunst zu rechnen, die Geometrie, Astronomie, Schriftzeichen, nebst vielen Arten von Spielen erfunden habe. Er soll zu den Zeiten des in Theben wohnenden, und über ganz Egypten herschenden Königs Thamus gelebt, und ihm in einer Unterredung, ausser seinen übrigen Künsten, die Kunst zu schreiben, als eine der heilsamsten Hülfsmittel und Unterstützungen des Gedächtnisses, empfohlen haben, gegen welche letztere der König aber mehrere Einwürfe machte. Sokrates rückt die Disputation des Theuths und Thamus, und die Gründe von beyden Seiten ein; es ist sonderbar, was man in diesen beyden Stellen alles übersehen hat' (my emphasis). For a more detailed discussion, see Thomas A. Szlezák, Platon und die Schriftlichkeit der Philosophie: Interpretationen zu den frühen und mittleren Dialogen (Berlin and New York: De Gruyter, 1985). 


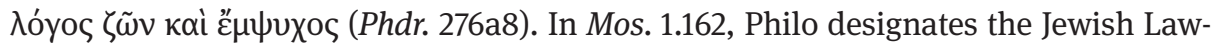




ple, through which he illustrates this aspect:

They know this well who read the sacred books, which, unless he was such as we have said, he would never have composed under God's guidance and handed on for the use of those who are worthy to use them, to be their fairest possession, likenesses and copies of the patterns enshrined in the soul, as also are the laws set before us in these books, which shew so clearly the said virtues. (Mos. 2.11) $)^{58}$

Philo applies Plato's critical analysis of literal language to his spiritual conception of Jewish law. This motif is quite a common one in Philo's Jewish Platonism. Accordingly, the biblical patriarchs, Abraham, Isaac and Jacob, also didn't require the written

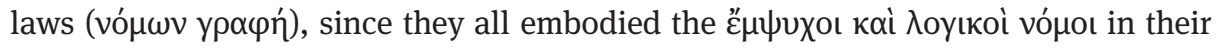
souls. ${ }^{59}$ We find a similar explanation in Mendelssohn's Jerusalem:

And now I am able to explain more clearly my surmise about the purpose of the ceremonial law in Judaism. The forefathers of our nation, Abraham, Isaac, and Jacob, remained faithful to the Eternal, and sought to preserve among their families and descendants pure concepts of religion, far removed from all idolatry. ${ }^{60}$

Philo strives ipso facto to accentuate the aliveness of the Godly unwritten law (őyp $\alpha$ -

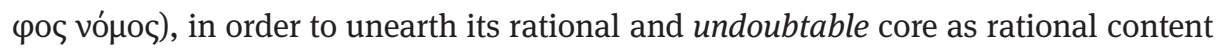
intrinsic to the human soul. This is very similar to the conceptual move made by Mendelssohn in Jerusalem with regard to the spiritual and dynamic Zeremonialgeset$z e$. In his important article "Das Zeremoniell als Zeichensprache," Daniel Krochmal-

57 The German translation of Mendelssohn's edition of De vita Moysis reads as follows: 'Vielleicht aber hat auch die göttliche Vorsehung Mosen lange vorher zu einem lebendigen und vernünftigen Gesetze gemacht, weil er einst ein Gesetzgeber werden sollte, und ihn im Voraus, ehe er es sich noch selbst in die Gedanken kommen ließ, dazu bestimmte;' see Gottesgelahrheit, 70 -71 (my emphasis).



58 PLCL 6.455-457 (my emphasis). For the German translation of this passage read by Mendelssohn, see: 'Es wissen aber diejenigen, welche die heiligen Bücher lesen, daß er diese nicht durch göttlichen Eingebung würde haben schreiben, noch denen, die sich dergleichen Güter zu bedienen wissen, das schönste Bild des vollkommensten Wesens, das jemals eine Seele gezieret hat, von welchem die bekannt gemachten Gesetze Abrisse und Nachahmungen sind, in denen man die vorher genannten Tugenden deutlich erblicket, hinterlassen können, wenn er nicht ein so vollkommener Mann gewesen wäre.' (Gottesgelahrheit, 149-150; my emphasis). Cf. Mendelssohn, Jerusalem, 128 (JubA 8, 191): 'Das allerhöchste Wesen hat sie [i.e. ewige Wahrheiten] allen vernünftigen Geschöpfen durch Sache und Begriff geoffenbaret, mit einer Schrift in die Seele geschrieben, die zu allen Zeiten und an allen Orten leserlich und verständlich ist' (my emphasis). Cf. Krochmalnik, "Das Zeremoniell als Zeichensprache,” 267273.

59 Abr. 5-6; Decal. 1.

60 Mendelssohn, Jerusalem, 117-118 (JubA 8, 183). 
nik stresses the rationality at the bottom of Mendelssohn's idea of ceremonial law as a distinct type of sign language of the religion of reason ('besondere Zeichensprache der Vernunftreligion'): ${ }^{61}$

\begin{abstract}
Mendelssohn spricht dem Judentum einen religiösen Lehrgehalt nicht ab; nur daß es sich dabei nicht um eine besondere Doktrin handelt, sondern um eine vernünftige Weisung, die durch besondere Zeremonien und die an sie anknüpfende maieutische Unterweisung vermittelt wird. Das Judentum zeichnet sich nicht durch eine besondere Lehre, sondern durch ein besonderes Medium der Vernunft aus. ${ }^{62}$
\end{abstract}

Thus, this Platonic rationalisation of Mosaic law underlying Mendelssohn's Zeremonialgesetz resembles, in its objective, that of Philo. Freudenthal aptly elucidates this aim as it pertains to Mendelssohn: 'The ceremonies of Judaism have a practical function similar to philosophy: they help buttress truths of reason against doubts. ${ }^{63}$

3) As previously mentioned, Mendelssohn's employment of the dichotomy between the inanimate word ('toter Buchstabe') and the living spirit ('lebendiger Geist') not only corresponds to Plato, but also and a fortiori to Paul according to 2 Corinthians 3:6. ${ }^{64}$ This can be demonstrated by juxtaposing a passage by Mendelssohn with an excerpt from Lessing's German translation of Juan Huarte de San Juan's The Examination of Men's Wits (Prüfung der Köpfe zu den Wissenschaften; 1752), a work that Mendelssohn apparently used for his own depiction:

Wir lehren und unterrichten einander nur in Schriften; lernen die Natur und die Menschen kennen, nur aus Schriften; [...] Alles ist toter
Wir schämen uns wollen sie sagen, unsre Entscheidung oder unsern Rath ohne Anführung eines Gesetzes zu geben, welches das was wir

61 Krochmalnik, "Das Zeremoniell als Zeichensprache," 242.

62 Ibidem, 272; Guttmann, Philosophie des Judentums, 314-135. See Mendelssohn, Jerusalem, 118 119 and 127-128 (JubA 8, 166 and 184).

63 Freudenthal, No Religion without Idolatry, 149.

64 See further Christiane Frey, "Geist und Buchstabe: Ideologeme der Darstellbarkeit bei Hamann, Mendelssohn und Kleist," in Darstellbarkeit: Zu einem ästhetisch-philosophischem Problem um 1800, eds. Claudia Albes and Christiane Frey (Würzburg: Königshausen \& Neumann, 2003): 143-156. 65 JubA 8, 170 (my emphasis).

66 Johann Huart (= Juan Huarte), Prüfung der Köpfe zu den Wissenschaften: Worinne er die verschiedenen Fähigkeiten die in den Menschen liegen zeigt einer jeden den Theil der Gelehrsamkeit bestimmt der für sie eigentlich gehöret und endlich den Aeltern Anschläge ertheilt wie sie fähige und zu den Wissenschaften aufgelegte Söhne erhalten können. Aus dem Spanischen übersetzt von Gotthold Ephraim Leßing (Zerbst: Zimmermannische Buchhandlung, 1752): 203-204 (my emphasis). It is noteworthy that Huarte makes use of Plato's understanding of the solicitor in this context; see ibidem, 206207 and 212-213. Cf. further Stephanie Catani, "Prüfung der Köpfe zu den Wissenschaften: Lessings Huarte-Übersetzung im Kontext poetologischer und anthropologischer Diskurse der Aufklärung," in 'ihrem Originale nachzudenken': Zu Lessings Übersetzungen, ed. Helmut Berthold (Tübingen: Niemeyer, 2008): 29-46. Cf. Gotthold E. Lessing, Lessing: Philosophical and Theological Writing, ed. Hugh B. Nisbet (Cambridge: Cambridge University Press, 2005), 63: 'In short, the letter is not the spirit, and the Bible is not religion. Consequently, objections to the letter, and to the Bible, need not also be objections to the spirit and to religion. For the Bible obviously contains more.' 
Buchstabe; nirgend Geist der lebendigen Unterhaltung. [...] Wir brauchen des erfahrenen Mannes nicht, wir brauchen nur seine Schriften. Mit einem Wort, wir sind litterati, Buchstabenmenschen. Vom Buchstaben hängt unser ganzes Wesen ab, und wir können kaum begreifen, wie ein Erdensohn sich bilden, und vervollkommnen kann, ohne Buch. ${ }^{65}$ entscheiden oder rathen ausdrücklich bestimmt. Dieser Bedeutung nach können die Gottesgelehrten keine Litterati heissen, weil in der h. Schrift ([II] Cor. III) der Buchstabe tödtet, der Geist aber lebendig macht. Ihr Buchstabe ist geheimnißvoll, voller Figuren und Bilder, dunkel und nicht einem jeden verständlich. Auch die Aertze haben keinen Buchstaben dem sie sich unterwerfen müßten. [...]; weil in der Medicin Vernunft und Erfahrung von weit grösserm Gewichte sind als das Ansehen. ${ }^{66}$

It seems almost beyond doubt that Mendelssohn relies, in these central passages out of Jerusalem, on Lessing's translation of Huarte's characterisation of the solicitor ('Rechtsgelehrter') in the eleventh section of his book. ${ }^{67}$ The main feature of the solicitor is his strong dependency on the literal letters of the law. These 'Rechtsgelehrten' as literalists (Litterati) are then contrasted by Huarte to biblical exegetes ('Gottesgelehrten'), who have the lively spirit as the guiding principle of their enquiry. Huarte goes on to make a distinction between incompetent legal scholars and competent ones, the former more reliant on the faculty of memory ('Gedächtnis'), the latter predominantly on the faculty of reason ('Verstand'). ${ }^{68}$ He then turns to implicitly equate the incompetent 'Gottesgelehrten' that constrain their whole being to the prosaic letters of the law with the negative mindset of Jews as a prime example of Litterati:

All which breedeth an alteration in the decision of the law, and if the judge or pleader be not endowed with discourse, to gather out of the law, or to take away or adjoine that which the law selfe doth not expresse in words, he shall commit manie errors in following the letter: for it hath been said that the words of the law are not to be taken after the Jewish manner, that is, to construe onely the letter, and so take the sense. ${ }^{69}$

Stumbling upon such a passage written by none other than his close friend Lessing, who, according to his own account, revered Huarte's scientific method of exploration

67 The title of this section, Huarte, Prüfung der Köpfe, 200, reads as follows: 'Worinne erwiesen wird, daß der theoretische Theil der Rechtsgelahrsamkeit dem Gedächtnisse, der practische Theil, das Amt nämlich der Advocaten und Richter, dem Verstande, die Regierung, aber des Staats der Einbildungskraft zugehöre.'

68 Ibidem, 210-211 and 213.

69 Juan Huarte de San Juan, The Examination of Mens Wits, trans. Richard Carew (London: Adam F. Slip, for Richard Watkins, 1594): 157-158 (my emphasis). For the German translation Mendelssohn used, see: 'thereof verba legis non sunt capienda iudaice. Das ist: die Worte des Gesetzes müssen nicht auf jüdische Art erklärt werden. Diese jüdische Art aber bestehet darinne, daß man eine grammatikalische Zergliederung damit anstellt und den buchstäblichen Sinne herauszieht;' see Huarte, Prüfung der Köpfe, 211 (my emphasis). 
by means of unbiased free thought alone, ${ }^{70}$ must have left a deep impression on Mendelssohn as he saw how his Jewish faith was being misrepresented. Certainly, this was not the first time Mendelssohn encountered such a critical evaluation of Judaism with respect to the Pauline distinction between the dead letter and the living spirit. For example, in Kritische Geschichte des Chiliasmus of Corrodi, a renowned Leibniz-Wolffian adherent to the enlightened 'Vernunftreligion', we find a similar negative assessment regarding Judaism as solely a spiritless 'Zeremonialreligion':

The Jewish rights, and constitutions do not, however, convey us a favourable opinion of this nation. We marvel at the appearance of legal scholars who constantly ignore the spirit of the law, and solely want to acknowledge its letter; who treat seriously and extensively the frivolities and wretched trifles, for which no law giver in the whole world cares; who issue prescriptions about unending improbable cases, of which no reasonable human being would conceive. We are surprised to find moral teachers which they follow who constantly ignore the eternal laws of nature, and decrees and constitutions of a very arbitrary essence, which seem to have no influence whatsoever on human happiness, and which have neither real morality nor immorality; were there ever teachers of religion, who took customs and ceremonies to be the sole essence of that religion, and were used to taking the outer shell and shadow of the virtue for the virtue itself, and perceiving the externality of religion for the interiority thereof [...] such teachers are the Jews. ${ }^{71}$

Mendelssohn's manner of dealing with these Christian prejudices is innovative. He inverts the Christocentric reading of 2 Corinthians 3:6 completely and gives it a Jewish twist: Henceforth, it is Judaism in its ancient original meaning that is the undogmatic religion of spirit, which does not rest on inanimate letters. Mendelssohn also does not retreat from the notion of Mosaic law. On the contrary: The dynamic nature of Mosaic 'Zeremonialgesetze' is precisely what gives Judaism its aliveness and frees it from being dependent upon the literal sense of Hebrew Scripture. ${ }^{72}$ In the closing

70 Gotthold E. Lessing, "Vorrede des Uebersetzers," in Huarte, Prüfung der Köpfe zu den Wissenschaften, [6b]: '[...] er beurtheilt und treibt alles auf eine besondere Art, er entdecket alle seine Gedanken frey und ist sich selbst sein eigner Führer.' Cf. Catani, "Prüfung der Köpfe zu den Wissenschaften," 31-32.

71 Corrodi, Kritische Geschichte des Chiliasmus, 92-93 (my translation): 'Die jüdischen Rechte, und Satzungen bringen uns indeß keine günstigere Meinung vom Charakter dieser Nation bey. Wir wundern uns, Rechtsgelehrte zu sehen, die den Geist des Gesetzes beständig aus den Augen setzen, und seinen Buchstaben allein gehalten wissen wollen, die Frivolitäten, und nichtswürdige Kleinigkeiten, um die sich kein Gesetzgeber in der Welt bekümmert, ernsthaft und weitläuftig abhandeln, die über unendlich unwahrscheinliche Fälle, an die kein vernünftiger Mensch denken wird, Verordnungen machen. Wir wundern uns Sittenlehrer zu finden, die die ewigen Naturgesetze unaufhörlich aus den Augen setzen, und Verordnungen, und Satzungen, die ganz willkürlich sind, und von ganz keinem Einfluß auf die menschliche Glückseligkeit scheinen, keine würkliche Sittlichkeit, oder Unsittlichkeit haben, an ihre Stelle setzen; gab es jemals Lehrer der Religion, welche Gebräuche und Ceremonien für das Wesen derselben nehmen, und sich gewohnt haben, die Schaale und den Schatten der Tugend für die Tugend selbst, und die äußere Seite für das Innwendige der Religion anzusehen, [...]; so sind die Juden solche Lehrer' (my emphasis).

72 For the influence of Wolffian philosophy on Mendelssohn's conception of the ceremonial law, see Krochmalnik, “Das Zeremoniell als Zeichensprache,” 255-259. 
part of Jerusalem, Mendelssohn places Jesus of Nazareth in the Jewish tradition of Halakha, for he is in complete agreement not only with Scripture, but also with the tradition. ${ }^{73}$ Mendelssohn would scarcely have a problem making the same conceptual move with the founding figure of Christianity, Paul, who does not speak of the abolition of Mosaic law, but rather, like Jesus (Matthew 5:17: $\pi \lambda \eta \rho \tilde{\omega} \sigma \alpha \mathrm{l}$ ), of its spiritual fulfilment (Romans 13:10: $\pi \lambda \eta \dot{\rho} \omega \mu \alpha$... vó $\mu$ ov). In sum, Mendelssohn attempts to break the reductionist equation of Jewish religion (spirit) with its Scriptural texts (letters), a stance he was already familiar with from Lessing's famous theological axiom for Christianity (1778): 'The letter is not the spirit, and the Bible is not religion.' ${ }^{74}$

4) Johann G. Herder has not been paid sufficient attention to his influence on Mendelssohn's growing scepticism towards language and its innate shortcomings. ${ }^{75}$ As Freudenthal has persuasively shown, Mendelssohn's growing doubt concerning the aptness of language for articulating metaphysical truths is not merely a transitional position we accidentally come across in Jerusalem, but rather constitutes a systematic philosophical stance of his later years that is also elaborated on in his Morgenstunden oder Vorlesungen über das Daseyn Gottes (1785). ${ }^{76}$ Herder's special appeal to Mendelssohn in this regard probably stems from the fact that he not only dealt with the pure theoretical elements of language, but also with an aesthetic analysis of Biblical Hebrew. ${ }^{77}$ He even personally reviewed in a very favourable manner Herder's work on language theory, Abhandlung über den Ursprung der Sprache (1772), in Friedrich Nikolai's Allgemeine deutsche Bibliothek 19.2 (1773). ${ }^{78}$ In Herder's Abhandlung über den Ursprung der Sprache, where he evaluates language as a profane

73 Mendelssohn, Jerusalem, 134 (JubA 8, 199). See Alexander Altmann’s commentary: Jerusalem, 239. Cf. Oswald Bayer, "Der Mensch als Pflichtträger der Natur Naturrecht und Gesellschaftsvertrag in der Kontroverse zwischen Hamann und Mendelssohn," in Mendelssohn und die Kreise seiner Wirksamkeit, eds. Michael Albrecht, Eva J. Engel and Norbert Hinske (Tübingen: Max Niemeyer Verlag, 1994): 184189.

74 Lessing, Lessing: Philosophical and Theological Writing, 63 and 127.

75 Cf. Ricken, "Mendelssohn und die Sprachtheorien der Aufklärung," 213 and 224-225.

76 Freudenthal, No Religion without Idolatry, 38-45.

77 Mendelssohn possessed, in his library, both Herder's Abhandlung über den Ursprung der Sprache (Berlin: Christian Friedrich Voß, 1772) as well as his Vom Geist der Ebräischen Poesie. Eine Anleitung für die Liebhaber derselben und der ältesten Geschichte des menschlichen Geistes (Dessau: Verlagskasse and Buchhandlung der Gelehrten und Künstler, 1782); see Verzeichni $\beta, 22$ (n⿳os 81-82), 53 (№ 655). Cf. Eva J. Engel, “'Die Freyheit der Untersuchung”: Die Literaturbriefe $72-75$ (13. und 20. Dezember 1759)," in Mendelssohn und die Kreise seiner Wirksamkeit, eds. Michael Albrecht, Eva J. Engel and Norbert Hinske (Tübingen: Max Niemeyer Verlag, 1994): 252 and 268.

78 JubA 5.2, 176: 'Ueberhaupt unterscheidet sich das philosophische Genie des Herrn Herders durch die Geschicklichkeit, alles was ihm seine ausgebreitete Kenntniß in der Philosophie, Naturkunde und der ganzen Litteratur darbot, zu seinem Vortheil anzuwenden, daher ist er auch vermögend, seine Materie in ein helleres Licht zu setzen, sie von mehrern Seiten zu betrachten, und mehr darinn zu entdecken, als es dem andern Verf. [i.e. D. Tiedemann] möglich war. [...] Herrn Herders Schreibart ist freylich stärker, aber auch geschmückter und glänzender; [...].' 
and animalistic product of human spirit ('überall Spuren vom Gange des menschlichen Geistes!'), ${ }^{79}$ he voices considerable doubt regarding the adequacy of artificial philosophical language, given its arbitrariness, for conveying absolute truths. ${ }^{80}$ The animalistic origin ('tierischer Ursprung') of language also pertains, as Herder argues, to the so-called Godly language of Biblical Hebrew. The writing style of this ancient language intuitively indicates this very fact, since it entirely contradicts the demands of common sense:

This manner of writing is so contrary to the course of sound reason-of writing the nonessential and omitting the essential-that it would be incomprehensible to the grammarians, if the grammarians were accustomed to comprehend. ${ }^{81}$

This sceptical attitude towards Biblical Hebrew as a language could account for Herder's shifting to explore the aesthetic dimensions of Hebrew Scripture. In his poetological analysis of the Hebrew Bible in Vom Geist der Ebräischen Poesie (1782), he constantly highlights sublimeness as a key feature of biblical poetic language ('Erhabenheit der Poesie'). This line of interpretation seems to mainly be a result of the preliminary study De sacra poesi hebraeorum praelectiones academicae oxonii habitae (1753), conducted by Robert Lowth, and of the extensive reception in the Enlighten-

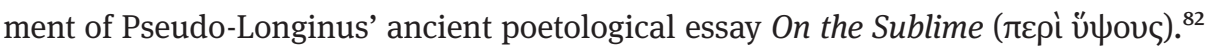
Very similar observations were already made by Mendelssohn between 1757 and 1758 in his review articles Betrachtungen ueber das Erhabene und Naive in den schönen Wissenschaften (1758) ${ }^{83}$ and De sacra poesi Hebraeorum, praelectiones academicae Oxonii habitae, a Roberto Lowth (1757), ${ }^{84}$ in which he favourably evaluates both Pseu-

79 Herder, Abhandlung über den Ursprung der Sprache, 133. Cf. to Karl W. Jerusalems essay: "Daß die Sprache dem ersten Menschen durch Wunder nicht mitgetheilt seyn kann," in Philosophische Aufsät$z e$, ed. Gotthold E. Lessing (Braunschweig: Buchhandlung des Fürstlichen Waisenhauses, 1776): 1-12. See Verzeichniß, 51 (№ 635).

80 Herder, Abhandlung über den Ursprung der Sprache, 43-44. See also ibidem, 60-61, 93 and 124125: 'Man weiß, auf welchen Wegen die meisten Abstraktionen "in unsre wissenschaftliche Sprache" gekommen sind, in Theologie und Rechtsgelehrsamkeit, in Philosophie und andre. Man weiß, wie oft die Scholastiker und Polemiker nicht einmal mit Worten ihrer Sprache streiten konnten und als Streit-


mußten, in denen die Begriffe abstrahirt, in denen das Streitgewehr geschärft war!,' as well as $133-134$ and 140.

81 On the Origin of Language: Jean-Jacques Rousseau Essay on the Origin of Languages, Johann Gottfried Herder Essay on the Origin of Language, trans. John H. Moran and Alexander Gode (Chicago and London: University of Chicago Press, 1986): 95; Herder, Abhandlung über den Ursprung der Sprache, 17; cf. ibidem, 111.

82 See Martin Fritz, Vom Erhabenen: der Traktat "Peri Hypsous” und seine ästhetisch-religiöse Renaissance im 18. Jahrhundert (Mohr Siebeck: Tübingen, 2011); Schorch, Moses Mendelssohns Sprachpolitik, 106-109; Libera Pisano, "Judentum, Entfremdung, Sprache. Der vergessene Zusammenhang zwischen Mendelssohn und Hegel," Judaica 4 (2016): 482-483.

83 JubA 1, 191-218.

84 JubA 4, $20-62$. 
do-Longinus' On the Sublime as well as Lowth's Latin lectures on the poetical nature of Scriptural Hebrew. ${ }^{85}$ Having said that, Herder's stance towards language in general and Biblical Hebrew in particular could have still helped form some of Mendelssohn's critical tendencies in Jerusalem: Like Herder, he was critical of language and saw an unbridgeable gap between arbitrary linguistic signs and that which they aim to signify. ${ }^{86}$ Herder's treatment of Biblical Hebrew as a deficient language with clear limitations and a mere derivative of the human spirit could have also led him to rule out the possibility of Holy Scripture entailing absolute philosophical truths. Mendelssohn also considered language in all its relativity as a criterion for evaluating the varying Bildungsniveaus of nations:

The Greeks had both culture and enlightenment. They were an educated nation just as their language is an educated language. - Generally, the language of a people is the best indication of its education, of its culture as well as its enlightenment, in terms of both its extent and its strength. ${ }^{87}$

It is therefore hardly surprising that Mendelssohn juxtaposes the sublime poetical language of Biblical Hebrew with the classic literature of ancient Greek and Roman poets of the stature of Homer and Virgil and implies the moral superiority of the former. ${ }^{88}$ The aesthetic approach is the manner in which Mendelssohn attempted to exhaust much of the lost meaning of the Hebrew Bible without resorting to unsubstantiated presuppositions of wishful thinking. ${ }^{89}$

5) Mendelssohn's sceptical analysis of semiotics may very well also be directly influenced by the Neo-Pyrrhonian critique of the Stoic theory of signs, which

85 Schorch, Moses Mendelssohns Sprachpolitik, 112-114; Pisano, "Judentum, Entfremdung, Sprache," 482-483.

86 Mendelssohn, Jerusalem, 108-112 (JubA 8, 173-177). See Herder, Abhandlung über den Ursprung der Sprache, 211.

87 Moses Mendelssohn, “On the Question: What Does ‘to Enlighten’ Mean?,” in idem, Philosophical Writings, trans. and ed. Daniel O. Dahlstrom (Cambridge: Cambridge University Press, 1997): 314; Moses Mendelssohn, "Über die Frage: was heißt aufklären," in Was ist Aufklärung? Thesen und Definition, ed. Ehrhard Bahr (Stuttgart: Reclam, 2004): 5 (JubA 6.1, 116).

88 Mendelssohn, De sacra poesi Hebraeorum, 171 (JubA 4, 20): 'Man liest den Homer, Virgil und die übrigen Schriften der Alten; man zergliedert alle Schönheiten, die darin enthalten sind, mit der größten Sorgfalt, und giebt sich alle Mühe, unsern Geschmack nach ihrem Muster zu bilden; aber selten bekümmert man sich um die Regeln der Kunst, nach welchen jene göttlichen Dichter unter den alten Hebräern die erhabensten Empfindungen in uns rege machen, und unmittelbar den Weg nach unserm Herzen zu treffend wissen. Der feine attische Geschmack, den wir aus den Schriften der alten Griechen und Römer schöpfen, kann sehr leicht in Weichlichkeit ausarten; aber der ächte orientalische Geschmack, der in den Schriften der heiligen Dichter herrscht, ist allzu männlich, allzu edel, als daß er uns je zu unwürdigen Gesinnungen verleiten könnte.'

89 For a more detailed discussion of Mendelssohn's aesthetic approach, see Daniel Krochmalnik, “Zeichen der Kunst, Zeichen der Moral, Zeichen der Religion," in Zur Religionsästhetik und -semiotik der Aufklärung, in Zeichen-Kunst. Zeichen und Interpretation, ed. Werner Stegmaier (Frankfurt am Main: Suhrkamp, 1999): 101-111. 
makes up a central part of the second book of Sextus Empiricus' Outlines of Pyrrhonism (PH II 97-133). ${ }^{90}$ In these two following chapters $\mathrm{x}$ and xi of book II, Sextus pres-



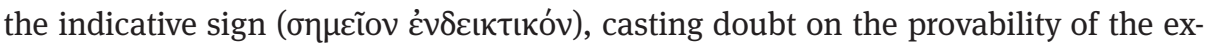
istence of the latter as a mental representation of the inherently ambiguous object of knowledge being signified ( $\sigma \eta \mu \alpha$ เvó $\mu \varepsilon v o v):{ }^{91}$ 'Thus, since such plausible arguments are adduced both for there being signs and for there not being, we should no more say that there are signs than that there are not. ${ }^{, 92}$ Indicative signs here are also strongly linked with discursive thought as they are defined as a sort of preposition ( $\lambda \varepsilon \kappa$ cóv), which is 'a pre-antecedent statement in a sound conditional, revelatory of the consequent. ${ }^{, 93}$ Mendelssohn's critical account of signs as irreal and arbitrary abstractions of human reason resembles Sextus' sceptical evaluation of Stoic semiotics:

[...]; for without the aid of signs, man can scarcely remove himself one step from the sensual. In the same way in which the first steps toward rational knowledge must have been taken, the sciences are still being expanded and enriched by inventions; this is why the invention of a new scientific term is, at times, an event of great importance. The man who first invented the word nature does not seem to have made a very great discovery. Nevertheless, his contemporaries were indebted to him for enabling them to confound the conjurer who showed them an apparition in the air, and to tell him that his trick was nothing supernatural, but an effect of nature. ${ }^{94}$

Three facts immediately suggest that Mendelssohn was acquainted with this specific section of Sextus' Outlines of Pyrrhonism: (i) Mendelssohn possessed the 1718 folio edition of Sextus' writings in his library, edited by Johann A. Fabricius on the basis of the original commentated edition of Henry Etienne from 1562. ${ }^{95}$ (ii) In addition, we also know that Mendelssohn was well familiar with Johann J. Bruckers Historia critica philosophiae, a five-volume work that he had its first edition (1742-1744) in his library ${ }^{96}$ and also reviewed its supplemented appendix published in 1767 in the Allgemeine deutsche Bibliothek 11.1 (1770). ${ }^{97}$ In Brucker's portrayal of the history of

90 Cf. Fogel, “Scepticism of Scepticism: On Mendelssohn's Philosophy of Common Sense,” 58-60. 91 PH II 99-101.

92 The translation used is Sextus Empiricus, Outlines of Scepticism, eds. and trans. Julia Annas and Jonathan Barnes (Cambridge: Cambridge University Press, 2000), 101 (PH II 133).

93 Sextus Empiricus, Outlines of Scepticism, 93 (PH II 101).

94 Mendelssohn, Jerusalem, 105-106 (emphasis in original; JubA 8, 171).

95 Verzeichniß, 3 (№ 35): Sextus Empiricus: Opera graece \& latine (Leipzig: Johann Friedrich Gleditsch und Sohn, 1718): 88-96 (PH II 10-11).

96 Verzeichniß, 8 ( $\mathrm{n}^{\circ} \mathrm{s}$ 59-64). Mendelssohn apparently had six volumes of this work, which might suggest that he also possessed the additional appendix (1767) of the second edition. Johann J. Brucker, Historia critica philosophiae, 5 vols. (Leipzig: Bernhard Christoph Breitkopf, 1742-1744).

97 JubA 5.2, 113-116. 
philosophy Sextus' critique of Stoic semiotics is discussed..$^{98}$ (iii) Mendelssohn also had in his possession Dietrich Tiedemann's System der stoischen Philosophie, ${ }^{99}$ where attention, in the section 'Von den Worten, und Ausdrücken der Gedanken' (143-172), is drawn to Sextus Empiricus' sceptical account of Stoic semiotics and conception of language. ${ }^{100}$

\section{Doubting Pythagoras' Golden Thigh}

Let us now turn to an important passage from the first part of Jerusalem, concerning scepticism, that is generally overlooked:

But should there be an end to all dispute on account of this? Must one never doubt principles? If so, men of the Pythagorean school could dispute forever how their teacher happened to come by his golden hip ('güldene Hüfte'), and no one would dare to ask: Did Pythagoras actually have a golden hip? Every game has its laws, every contest its rules, according to which the umpire decides. If you want to win the stake or carry away the prize, you must submit to the principles. But whoever wishes to reflect on the theory of games may certainly examine the fundamentals. Just as in a court of law. ${ }^{101}$

In this citation, Mendelssohn grapples with the vicious prejudiced critique of the reviewer of his Vorrede to Menasseh Ben Israel's Rettung der Juden in Göttingische Anzeigen von gelehrten Sachen, published on the $14^{\text {th }}$ of September 1782. The central point of the dispute, from the perspective of the reviewer, was that Mendelssohn calls into question the right to apply Prussian ecclesiastical law, predicated on Christian doctrines, ${ }^{102}$ to Jewish communities. ${ }^{103}$ The reviewer does not refrain from exhibiting his negative sentiments towards the Jewish people, ${ }^{104}$ which he tries to validate with reference to anti-Judaic works such as Johann A. Eisenmenger's Entdecktes Judenthum. ${ }^{105}$ The sudden dogmatic conclusion of the reviewer ('all this is new and harsh. First principles are negated, and all dispute comes to an end') ${ }^{106}$ is exactly the point of departure for Mendelssohn. 'Die ersten Grundsätze' of the ecclesiastical

98 Brucker, Historia critica philosophiae, 1.1338-1339.

99 Verzeichniß, 48 ( $\mathrm{n} \mathrm{o}_{\mathrm{s}}$ 578-581); Dietrich Tiedemann, System der stoischen Philosophie, 3 vols. (Leipzig: Weidmanns Erben und Reich, 1776).

100 Ibidem, vol. 1, 167-169.

101 Mendelssohn, Jerusalem, 81 (JubA 8, 148-149).

102 Göttingische Anzeigen von gelehrten Sachen (III. Stück) (14.09.1782): 893: 'Recht [...], das mit Lehrmeinungen zusammenhängt und auf demselben beruht.'

103 Ibidem: 'Aus dieser Insinuation mußten wir nothwendig schliessen, daß man dem königl. Preuss. Justizdepartement eigentlich begreiflich machen wollte, kein christl. Justizcollegium könne die Juden richten; dies sey die Sache der Rabbiners; [...].'

104 Ibidem, 892: ‘die gemeinschädlichen Grundsätze der Juden [...] Unarten ihrer Väter’ etc. 105 Mendelssohn was familiar with this work; see Verzeichniß, 18 (№ 301); JubA 13, 49-50.

106 Mendelssohn, Jerusalem, 81 (JubA 8, 148). 
authority by definition, as Mendelssohn argues, cannot be proven. He then goes on to implicitly identify this attitude with the dogmatism of the Pythagorean school. Similarly, in the fourth part of Judah Halevi's Kuzari, the Pythagorean school of thought is referred to in the context of the impossibility for philosophy to reach a final verdict on metaphysical principles:

Neither do two philosophers agree on this point, unless they be disciples of the same teacher. But Empedocles, Pythagoras, Aristotle, Plato, and many others entirely disagree with each other. ${ }^{107}$

Like Mendelssohn, Halevi points to the dogmatic and tribal nature of different philosophical schools, whose disciples agree solely with their own philosophical masters. Mendelssohn was also well acquainted with Diogenes Laërtius' Lives and Opinions of Eminent Philosophers, ${ }^{108}$ where the myth of Pythagoras' golden thigh is mentioned. ${ }^{109}$ With that said, I want to advance the argument that Mendelssohn's depiction is actually derived from Johann M. Schröckh's fourth volume of his monumental work Christliche Kirchengeschichte (1777), where we find the following description:

These are rumors and tales of the later Pythagoreans; many of them unreasonable and suspicious, many of them cannot even be traced back, with certainty, to a specific time, and the seeming imitation of the evangelical history takes away its entire full worth and true usage. [...] He [i.e. Pythagoras] cured diseases of the body and the soul with magical sayings and was regarded because of his golden thigh to be Apollo. Had the Christians propagated similar tales, with so little believability, about the founders of their religion: then they would have been rightly ridiculed. Apart from that, they were not yet entitled to designate Pythagoras as a deceiver, insofar as one cannot longer establish anything in regards to this otherwise wise and virtuous man other than, at the utmost, the fact that he concealed a great deal of his doctrines and employed them against the large heap of artificial conceptions, which he might have perceived as necessary. But the Christians could have then even further advanced their accusation of the credulity against his adorers. ${ }^{110}$

107 Judah Halevi, The Kuzari. An Argument for the Faith of Israel, trans. Hartwig Hirschfeld (New York: P. Shalom, 1969): 239 (my emphasis; the Hebrew translation used by Mendelssohn reads as fol-

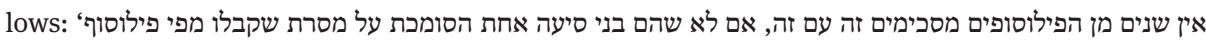

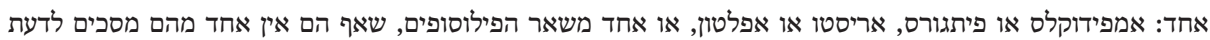
חברו.'). Cf. Sacks, who quotes the very same passage of Halevi with reference to Mendelssohn's Jerusalem. But he does this in order to show that 'Mendelssohn [...] diverges significantly from Halevi regarding philosophical change,' see Sacks, Living Script, 207-208. For the influence of Simone Luzzatto on Mendelssohn's Jerusalem, see Veltri, Renaissance Philosophy in Jewish Garb, 221.

108 See Verzeichniß, 26 (№ 149).

109 Diogenes Laërtius, The Lives and Opinions of Eminent Philosophers (London: Bohn's Classical Library, 1853): 342: 'He is said to have been a man of the most dignified appearance, and his disciples adopted an opinion respecting him, that he was Apollo who had come from the Hyperboreans; and it is said, that once when he was stripped naked, he was seen to have a golden thigh [Tòv $\mu \eta \rho \dot{v} v$ ó $\varphi \theta \tilde{\eta}$ -

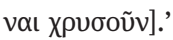

110 My translation of Johann M. Schröckh, Christliche Kirchengeschichte, vol. 4 (Leipzig: Engelhart Benjamin Schwickert, 1777), 348-349: 'Es sind Gerüchte und Erzählungen der spätern Pythagoräer; 
The parallels to Mendelssohn's account are striking: Both descriptions exploit the myth of Pythagoras' thigh ('güldene Hüfte') to exemplify the problems of dogmatism. Schröckh tries to delineate the substantial difference between these implausible tales ('Erzählungen') about Pythagoras, passed on by the anti-Christian Porphyry, and the written transmission regarding the figure of Jesus. He claims that if the Christians propagated such farfetched rumours about the founders of their religion, they would have deserved much ridicule. Mendelssohn, on the other hand, attempts to show that this is already, to some degree, the case concerning ecclesiastical authority ('Kirchenmacht') in the Prussian Kingdom, since its 'fundamental principles' are adhered to dogmatically by the majority of the Christian population without asking whether they are adequate and rational. If Mendelssohn really bases his passage on Schröckh's unfavourable characterisation of Pythagoreans, then his implicit statement against Prussian Christians is quite critical: They warrant mockery for their gullibility ('Leichtgläubigkeit'). The way Mendelssohn illustrates the ludicrousness of the assessment of his reviewer is through the sceptical metaphor of a game in which rules can be arbitrarily made up. It should be noted that the correlation between sceptical doubt and the contingency of the predetermined rules of a game is not foreign to Jewish thought. Already in Simone Luzzatto's treatise Socrates or on Human Knowledge (1651) we find a very similar sceptical observation with recourse to the arbitrarily defined 'first positions' of a chess game:

Hence, I likewise started to suspect that as human beings we are indeed not endowed with sufficient organs and faculties to apprehend and acknowledge the truth. Besides, the early bases and foundations from which the edifice of human knowledge rises are indeed not fixed and stable, but arbitrary and laid at our whim, as is usually the case with games, especially with chess, where similarly, while deductions and consequences are necessary, the first positions are indeed contingent and voluntary. ${ }^{111}$

viel Ungereimtes und Verdächtiges, vieles das nicht einmal auf eine sichere Zeitrechnung zurück geführt werden kann, und die augenscheinliche Nachahmung der evangelischen Geschichte benimmt ihren vollends allen Werth und wahren Gebrauch. [...] Krankheiten des Leibes und der Seele heilte er durch Zaubersprüche, und wurde wegen seiner güldenen Hüfte vor den Apollo gehalten. Hätten die Christen solche Erzählungen, und mit so geringer Glaubwürdigkeit, von den Stiftern ihrer Religion ausgebreitet: so würden sie mit Recht verspottet worden seyn. Im übrigen waren sie zwar dadurch noch nicht berechtigt, den Pythagoras einen Betrüger zu nennen, weil man von diesem sonst weisen und tugendhaften Manne höchstens nicht mehr beweisen kann, als daß er viele seiner Lehrsätze verheimlicht, und gegen den großen Hauffen Kunstbegriffe, die er vielleicht vor nothwendig hielt, angewandt habe. Aber seinen Bewunderern konnten die Christen desto mehr eine unwürdige Leichtgläubigkeit vorwerfen' (my emphasis). The fifth volume was, for example, reviewed in Friedrich Nicolai's journal Allgemeine deutsche Bibliothek 40.1 (1780): 536-540, where Mendelssohn reviewed numerous works between 1765 and 1784; see JubA 5.2. Cf. AdB 23 (1774), 375: 'Aristoteles, der in seinen exoterischen Schriften gemeinnützige Materien für den Bürger gemeinnützig vortrug, war ein weiser Mann; aber der Pythagoras, der eine goldene Hüfte vorgab, aus der Hölle zurückkam und sich die Rüstung des Euphorbus zueignete, war ein Charlatan.'

111 The translation of this passage used here is taken from Giuseppe Veltri, "Negotiating the Principle of (Non)-Contradiction: Johann Frischmuth on the Rabbinic Dialectic Discussion," in Yearbook 
To a Prussian Jew such as Mendelssohn, looking at mainstream Christian society from the outside, these rules are extraneous and can be randomly modified. And it seems quite evident that he is not only interested in tackling the ecclesiastical laws ('Kirchenrechte'), but also that which is at their core: Christian doctrines ('Lehrmeinungen'). With this example, one can see how sceptical thought patterns also entered Mendelssohn's practical Weltanschauung.

\section{Summary}

In conclusion, it can be said that Mendelssohn's perspective underlying the main apologetic contentions of his Jerusalem is a philosophical, sceptical one: He assumes that religion cannot withstand the scrutinizing assaults of philosophy and for that reason attempts to secure his own Jewish belief as a non-theoretical religion based primarily on the practical notion of ceremonial law. In order to ward off these threats, Mendelssohn has to compromise on a very central and common premise of traditional Jewish belief: The view that the Hebrew Bible manifests absolute truth. Hebrew Scripture can, at most, facilitate the attainment of common-sense knowledge regarding natural religion. But Mendelssohn did not seem much discouraged by this fact, as he also appreciated the aesthetic dimensions of poetical Biblical Hebrew, a field that was rapidly gaining ground in the second half of the eighteenth century in German-speaking Europe. At the same time, the critical analysis of Biblical texts was emerging as a very promising method; it certainly also had an effect on Mendelssohn's unconditioned refutation of both Maimonidean as well as kabbalistic understanding of Scripture as speculative texts.

I then turned to uncovering Mendelssohn's intricate usage of numerous philosophical and theological sources, which he seems to utilise for his sceptical account of language. It was demonstrated that Mendelssohn's critical discussion takes for its starting point Cranz's employment of Pauline metaphor (2 Corinthians 3), through which he distinctively demarcates Judaism from Christianity by highlighting the mediatory role of symbolic language taken at face value. Mendelssohn then proceeds to philosophically develop his sceptical attitude towards language, drawing upon the Platonic Schriftkritik in the Phaedrus. Subsequently, I went on to suggest that Mendelssohn's preferred solution for the problem of dependency upon Hebrew Scripture, the ceremonial law, can also be linked to Plato's critical analysis of the written word. As shown above, Mendelssohn had first-hand knowledge of Philo's De vita Moysis, to which he refers a number of times in his Bi'ur. In this allegorical exegesis, Philo incorporated Plato's Schriftkritik and appraisal of the dynamic aliveness of spoken lan-

of the Maimonides Centre for Advanced Studies 2017, ed. Bill Rebiger (Berlin and Boston: De Gruyter, 2017): 114. I would like to thank Giuseppe Veltri for drawing my attention to this insightful passage of Simone Luzzatto. The first English translation of Socrates, a project undertaken both by Giuseppe Veltri and Michela Torbidoni, is expected to be published soon. 



saic law and accordingly conceptualises it as not being confined to inanimate written

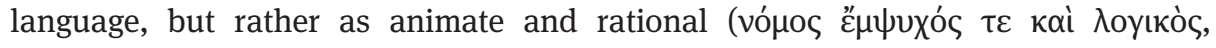
Mos. 1.162). Additionally, it was shown that Mendelssohn, within the context of his critique of language, elaborates on 'das echte Judentum,' based on the idea of ceremonial law, by apologetically appropriating the well-known Pauline dichotomy of letter and spirit. However, he does not do so directly, but through the mediation of Lessing's German translation of Juan Huarte de San Juan's The Examination of Men's Wits, where legal scholars and Jewish exegetes of the Bible are both depicted as Litterati. Mendelssohn simply semantically inverts this anti-Judaic understanding of the Pauline dichotomy of the inanimate letter and the animate spirit: Judaism in its 'ancient, original' sense orients itself by the lively spirit of the ceremonial acts ('Zeremonialhandlungen') of Mosaic law; it is Christianity as a revelatory religion ('geoffenbarte Religion') that relies heavily on the inanimate letters of its various speculative 'Heilswahrheiten' and is to be regarded as 'a yoke in spirit and in truth $^{\text {,112 }}$ for its followers. Moreover, I attempted to point to the plausible impact that both Herder's philosophy of language as well as the Neo-Pyrrhonian scepticism of Sextus Empiricus might have had on Mendelssohn's critical attitude towards signs and language.

Lastly, I illustrated how Mendelssohn uses sceptical strategies to call the ecclesiastical laws and the Christian doctrines upon which they are grounded into question. He challenges them by presenting the distinctive example of the myth of Pythagoras's golden thigh, which the Greek philosopher's dogmatic devotees don't dare to doubt. In so doing, Mendelssohn wishes to reveal the vulnerability of Christian dogmatism to philosophical scepticism. Analogous to the rules of a game, the starting points, the fundamental Principles ('die ersten Grundsätze'), are selected arbitrarily and can for that very reason be superseded and substituted at any time. I pointed out the possible influence the fourth part of Judah Halevi's Kuzari might have had on Mendelssohn at this point, since he portrays Pythagoras' adherents as dogmatic within the wider context of metaphysical abeyance between the various philosophical schools. I ultimately presented the fourth volume of Schröckh's Christliche Kirchengeschichte as a more plausible source for this particular passage, since it also mentions Pythagoras' golden thigh in conjunction with both unfounded dogmatism and the question of the authenticity of Christian doctrines.

Mendelssohn's metaphorical portrayal of the asymmetrical relation between Judaism and Christianity as a somewhat unstable, multi-story building is quite illustrative for our theme at hand. ${ }^{113}$ In this simile, Judaism is placed on the solid ground floor, while speculative Christianity inhabits one of the upper floors of the same

112 Mendelssohn, Jerusalem, 248 (Appendix: Draft of Jerusalem).

113 This simile is, of course, an allusion to Cranz: Das Forschen nach Licht und Recht, 23-24. See Alexander Altmann's introduction for commentary on this simile: Jerusalem, 10, 203-204. 
building. The advantage of undogmatic Judaism resides in its secure position and, as a result, its protection from attacks by sceptical philosophy. ${ }^{114}$ The chief aim of Mendelssohn's Jerusalem can be derived from this particular point of view: it is an attempt to conceptually fortify the Jewish Religionsgebäude ${ }^{115}$ against persistent sceptical doubt. But one should not be so mistaken as to believe Jesus or Paul occupy the upper floor.

114 Cf. Mendelssohn, Jerusalem, 248 (Appendix: Draft of Jerusalem).

115 Cranz, Das Forschen nach Licht und Recht, 26. 